\title{
Rheumatic mitral stenosis simulating double-orifice mitral valve
}

\author{
Himanshu Mahla, Shivakumar Bhairappa, Prabhavathi Bhat, \\ Cholenahally Nanjappa Manjunath
}

Department of Cardiology, Sri Jayadeva Institute of Cardiovascular Sciences and Research, Bangalore, Karnataka, India

\section{Correspondence to} Dr Shivakumar Bhairappa, snbhairappa@gmail.com
To cite: Mahla $\mathrm{H}$ Bhairappa S, Bhat $P$, et al. BMJ Case Rep Published online: [please include Day Month Year] doi:10.1136/ bcr-2013-200090

\section{DESCRIPTION}

A 46-year-old woman presented to us with symptoms of breathlessness New York Heart Association class II for 6 months on and off with a history of rheumatic fever in childhood. She was diagnosed in the periphery as having rheumatic heart disease for 20 years. The patient was on regular injectable penicillin prophylaxis (injection penicillin 1.2 million units every 21st day), $\beta$-blockers with intermittent diuretics. Cardiac examination revealed low pitched mid-diastolic rumble grade III/VI at apex with normal S1.

Twelve-lead ECG showed atrial fibrillation with controlled ventricular rate. Echocardiogram revealed moderate mitral stenosis with severe subvalvular disease. Severe subvalvular fusion created double orifice appearance (figures 1 and 2). The combined mitral valve area of two orifices was approximately $1.5 \mathrm{~cm}^{2}$ (figure 3 ), gradient was only $8 / 5 \mathrm{~mm} \mathrm{Hg}$ (figure 4). This valve was unsuitable for percutaneous valvotomy due to severe subvalvular

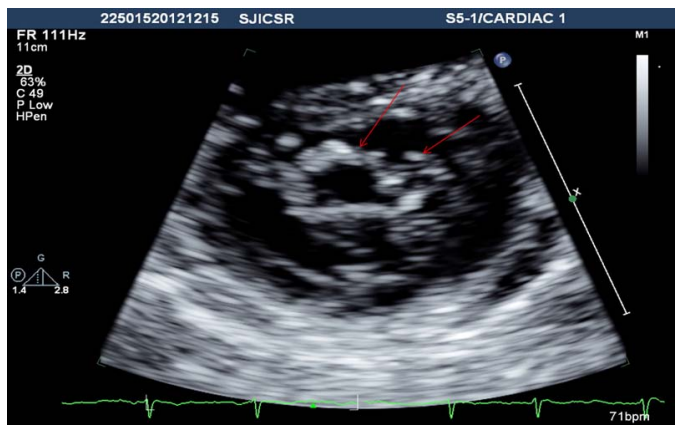

Figure 1 Modified short axis view showing two mitral orifices.

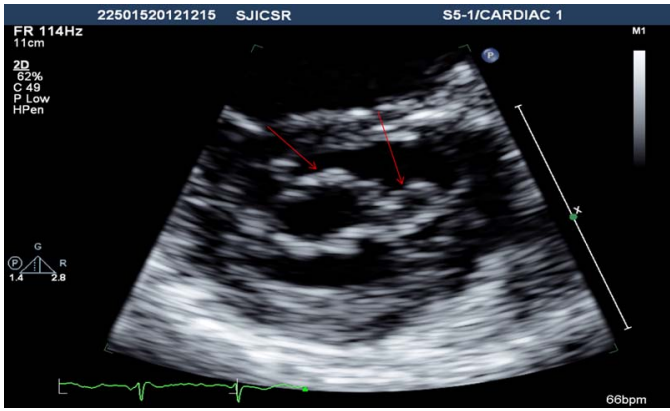

Figure 2 Modified short axis view showing two mitral orifices (in different angulation).

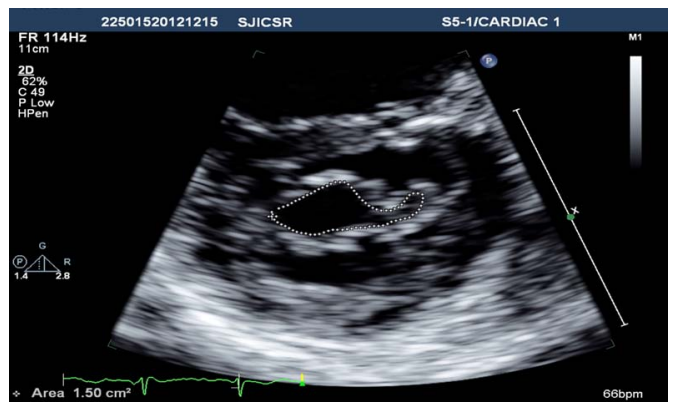

Figure 3 Modified short axis view showing mitral valve area.

disease (videos 1-4). The patient underwent mitral valve replacement with mechanical bileaflet valve. She is doing well on follow-up.

The valve described here, resembled doubleorifice mitral valve (DOMV). Differentiating features were history of rheumatic fever in childhood, thickened valve leaflets, severe subvalvular disease with existence of two papillary muscles.

Most common cause of mitral stenosis is rheumatic heart disease. ${ }^{1}$ Twenty five percentage of rheumatic heart disease patients have isolated mitral stenosis, 40\% have combined stenosis and regurgitation. $^{12}$ About $70 \%$ of all patients with rheumatic mitral stenosis are women. Diagnostic findings on echocardiography are leaflet thickening, chordal shortening with fusion. DOMV may be stenotic, regurgitant or normal. ${ }^{3}$ Commonly associated anomalies with DOMV are atrioventricular, ventricular or atrial septal defects, Ebstein anomaly, tetralogy of Fallot, coarctation of aorta.

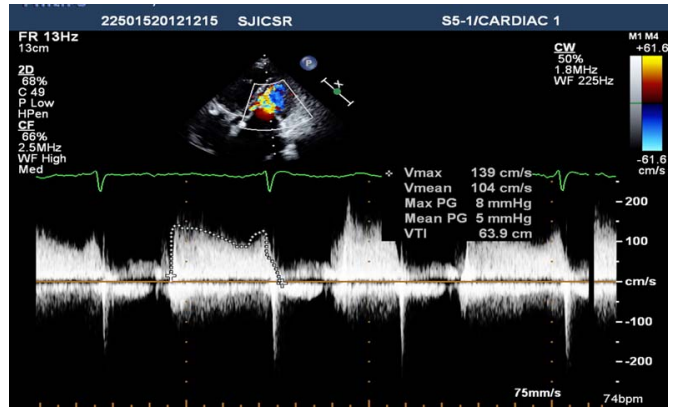

Figure 4 Apical four-chamber view with calculation of gradient across mitral valve. 


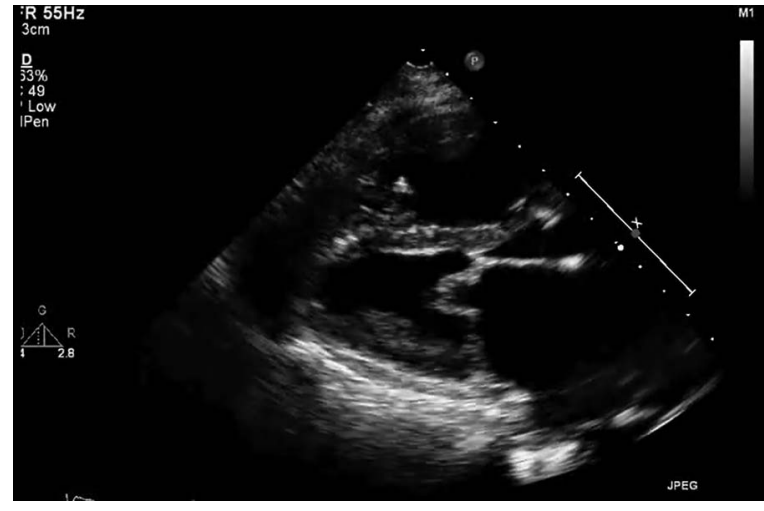

Video 1 Parasternal long axis view showing subvalvular disease.

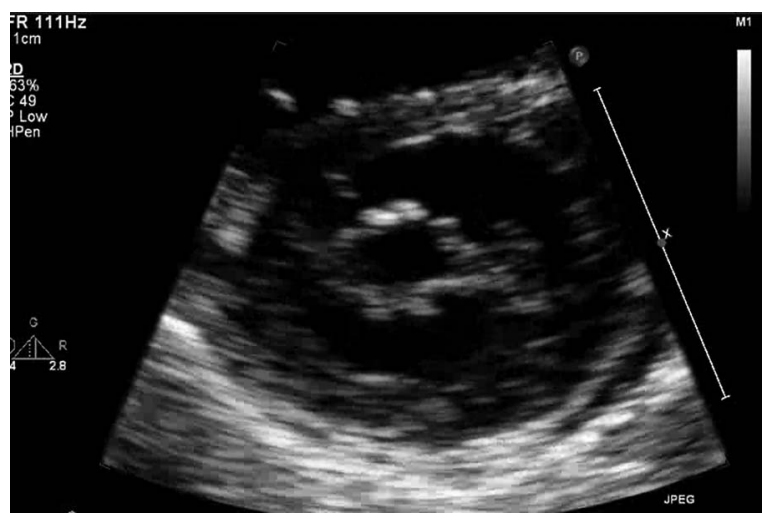

Video 2 Parasternal short axis view showing valvular \& subvalvular orifice.

Video 3 Parasternal short axis view with colour Doppler showing 2 jets of forward flow through mitral valve(1 from valvular orifice and other from subvalvular orifice).

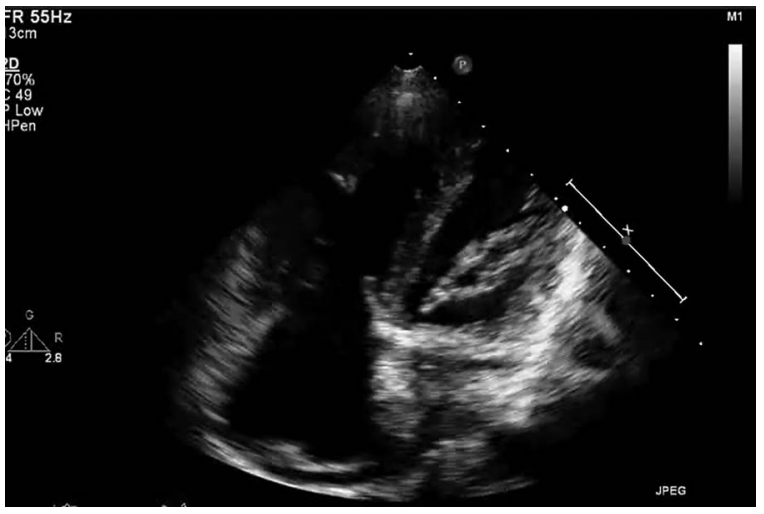

Video 4 Apical 4 chamber view showing subvalvular orifice.

\section{Learning points}

- Rheumatic mitral stenosis can simulate double-orifice mitral valve in presence of severe subvalvular fusion.

- Meticulous echocardiographic examination can differentiate between two entities by taking different views and also reduce the financial burden for the patient for costlier investigations like 3 dimensional echocardiogram.

- Parasternal short axis view taken alone can be quite confusing.

Contributors All authors were involved in the patient care and the manuscript writing.

Competing interests None.

Patient consent Obtained.

Provenance and peer review Not commissioned; externally peer reviewed.

\section{REFERENCES}

1 Rahimtoola SH, Durairaj A, Mehra A, et al. Current evaluation and management of patients with mitral stenosis. Circulation 2002:106:1183.

2 Mensah GA. The burden of valvular heart disease. In: Otto CM, Bonow RO. eds. Valvular heart disease: a companion to Braunwald's heart disease. Philadelphia: Saunders/Elsevier, 2009:1-18.

3 Baño-Rodrigo A, Van Praagh S, Trowitzsch E, et al. Double orifice mitral valve: a study of 27 postmortem cases with developmental, diagnostic \& surgical considerations. Am J Cardiol 1988;61:152

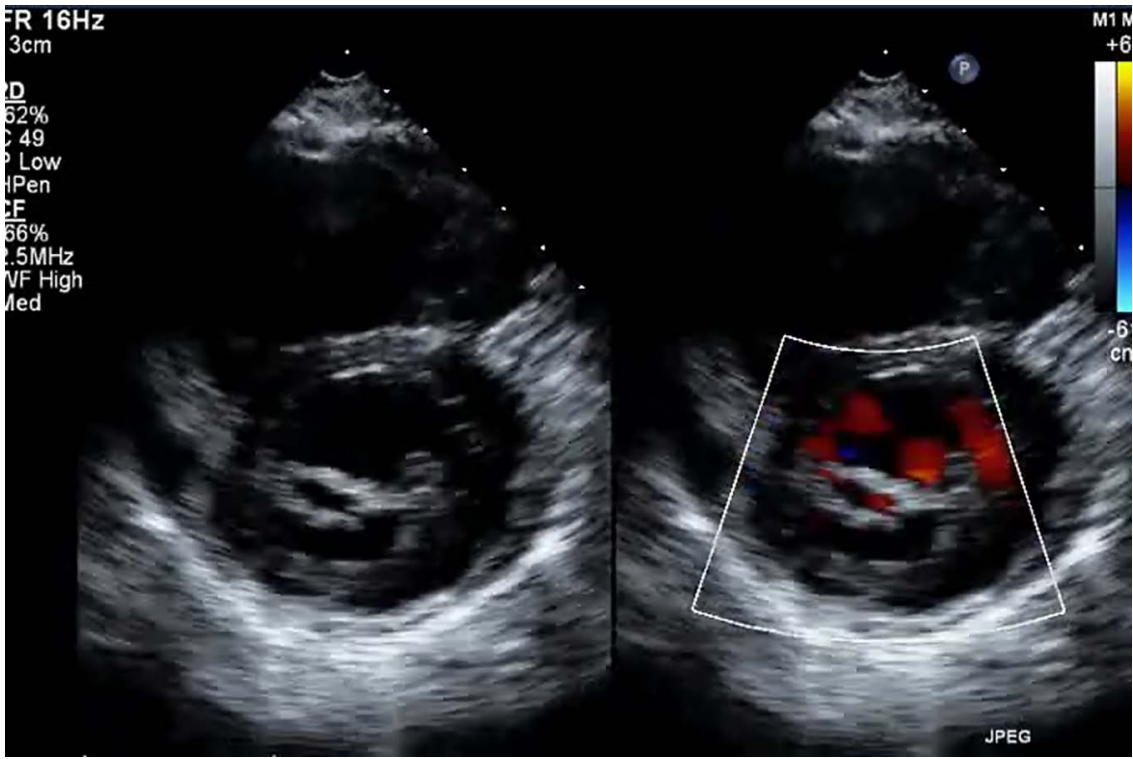


Copyright 2013 BMJ Publishing Group. All rights reserved. For permission to reuse any of this content visit http://group.bmj.com/group/rights-licensing/permissions.

BMJ Case Report Fellows may re-use this article for personal use and teaching without any further permission.

Become a Fellow of BMJ Case Reports today and you can:

- Submit as many cases as you like

- Enjoy fast sympathetic peer review and rapid publication of accepted articles

- Access all the published articles

- Re-use any of the published material for personal use and teaching without further permission

For information on Institutional Fellowships contact consortiasales@bmjgroup.com

Visit casereports.bmj.com for more articles like this and to become a Fellow 